\title{
Green manure and compost effects on N-P dynamics in Mediterranean organic stockless systems
}

\author{
Corrado Ciaccia ${ }^{1 *}$, Francesco Ceglie ${ }^{2}$, Fabio Tittarelli ${ }^{1}$, Daniele Antichi ${ }^{3}$, Stefano Carlesi $^{4}$, Elena \\ Testani $^{1}$, Stefano Canali ${ }^{1}$ \\ ${ }^{I}$ Consiglio per la ricerca in agricoltura e l'analisi dell'economia agraria. Centro di ricerca Agricoltura e Am- \\ biente (CREA - AA), Via della Navicella, 2 - 00184, Roma (RM), Italy. ${ }^{2}$ Organic farming department, Mediter- \\ ranean Agronomic Institute of Bari-CIHEAM-MAIB, via Ceglie 9, 70010 - Valenzano (BA), Italy. ${ }^{3}$ Centre for \\ Agri-environmental Research "Enrico Avanzi”, University of Pisa, Via Vecchia di Marina 6, 56122 San Piero \\ a Grado (PI), Italy. ${ }^{4}$ Institute of Life Sciences, Scuola Superiore Sant'Anna - Piazza Martiri della Libertà 33 - \\ 56127 Pisa, Italy.*Corresponding author: corrado.ciaccia@crea.gov.it
}

\begin{abstract}
Stockless systems, where plant and animal production are uncoupled, represent a common condition in Mediterranean areas. In organic systems, soil fertility is mainly managed by green manures, whereas composts of plant origin represent suitable soil conditioners. The low P content of these materials, together with the shortage of animal waste availability, determine potential nutrient depletion overtime and, in calcareous soils, P mining conditions. In a two-year field experiment in Central Italy, the effect of green manure vetch (Vicia villosa) (GM+) was compared with a control left fallow (GM-), combined with P-based fertilizers (F) on organic maize (Zea mays). Yields and N-P dynamics were evaluated by direct measurements, nutrient balance and efficiency index. $\mathrm{N}$ balance was higher than in GM+ GM- (+71.8 and $-23.6 \mathrm{~kg} \mathrm{~N} \mathrm{ha}^{-1}$, respectively). P enriched compost with RP (rock-phosphate) (EP), showed significant improvement in P use efficiency (meanly $+34 \%$ ) than other treatments (unfertilized control (RP), not P enriched compost (NEP)) and P equilibrium in the short run. On the other hand, P-fertilizers and maize residues soil incorporation determined $P$ surplus in a long perspective (up to $+10 \mathrm{~kg}$ $\left.\mathrm{P} \mathrm{ha}^{-1}\right)$. Results emphasize the possibility of $\mathrm{P}$ reintegration in stockless organic systems without animal wastes.
\end{abstract}

Keywords: Enriched compost, rock phosphate, surface balance, nutrient use efficiency 


\section{Introduction}

The main challenge of modern agriculture is to feed the increasing world population through a sustainable resource use (Schulte et al., 2013). Organic farming can contribute to achieve this goal, being driven by biodiversity, biological cycles and based on agroecological principles (Rahmann et al., 2016). Nevertheless, organic farming is worldwide characterized by a yield gap with the conventional agriculture, estimated in $-25 \%$, on average, depending on the geographical area and the production system (Reganold and Wachter, 2016; De Ponti et al., 2012). The poor soil fertility management and the inadequate nutrient supply are recognized among the main constraints to bridge the gap, inside organic farming, between best practices and the real current productive systems (EIPAGRI Focus Group, 2014). In such a scenario, achieving a balance between inputs and outputs of nutrients within the farm system is critical to ensure both shortterm productivity and long-term sustainability (Watson et al., 2002). Furthermore, high nutrient use efficiency can be crucial both to ensure acceptable crop yields and to improve environmental sustainability, as well as economic viability of organic systems. Indeed, the integrated use of green manures and organic amendments (i.e. compost) is a feasible technique to optimize $\mathrm{N}$ fertility. At the same time this management strategy contributes to enhance organic $\mathrm{C}$ inputs to soil, thus contributing to long term soil quality and fertility (Mazzoncini et al., 2010). The use of amendments can further determine a residual effect for the subsequent crop in the rotation (Eghball et al., 2004). Many authors highlighted the need to match the nutrient availability with crop requirements (Mahmood et al., 2016; Canali et al., 2012). This is relevant mainly for nitrogen $(\mathrm{N})$, characterized by a great mobility into the soil-plant system and, consequently, by a high risk of losses, e.g. by leaching (Shah et al., 2016). The rate of $\mathrm{N}$ release from fertilizers, amendments and other organic materials (i.e. plant residues) used to manage soil fertility and the plant $\mathrm{N}$ requirements should be carefully considered in order to design successful $\mathrm{N}$ fertilization strategies. In particular, the $\mathrm{C} / \mathrm{N}$ ratio, which is usually considered as an indicator of the likely net mineralization of organic materials incorporated into soils, is a useful parameter to foresee the expected equilibrium between the fraction of soil $\mathrm{N}$ being mineralized and the organic fraction remaining in the soil and contributing to the long term $\mathrm{N}$ pool. It follows that, combining different organic $\mathrm{N}$ sources having different characteristics it might be possible to modulate soil $\mathrm{N}$ availability to plants and synchronize $\mathrm{N}$ release with plant requirements (Canali et al., 2012). In such a scenario, livestock have traditionally had a relevant role in organic farming, as source of organic materials (i.e. manure) and nutrients. However, in respect with the food security issue, it is likely that in the future the livestock density might be reduced at global level. Therefore, the study of the performances of organically managed stockless cropping systems become even more relevant, as currently discussed in the frame of the so-called Organic 3.0 concept, in order to position organic farming as a modern, innovative system, able to answer to the agriculture challenges of the next future (Rahmann et al., 2016).

Soil management strategies based on combined use of green manures and green (plant origin material) composts are a suitable option to manage soil fertility especially in stockless systems (Stinner et al., 2008), which represent a common condition in the Mediterranean area. Indeed, in these areas, plant production and animal husbandry are often not functionally connected as separated in space. Consequently, the stockless systems are inherently characterized by the scarcity of organic matter and nutrients (mainly N) of 
animal origin to be recycled into the soil (Migliorini et al., 2014). On top of that, the organically managed stockless systems have to rely with the restrictions imposed by the EU Regulation on organic farming (Council Regulation [EC] n. 834/07 [EC, 2007]) in terms of utilization of off-farm organic fertilizers and amendments. However, due to the poor phosphorus (P) content of green manures and green composts, soils of stockless systems are generally characterized by P mining conditions (Nelson and Janke, 2007; Watson et al., 2002). Moreover, in Mediterranean area, soils are often characterized by a high calcareous composition, which favors $\mathrm{P}$ insolubility due to the formation of $\mathrm{Ca}-\mathrm{P}$ complexes and further reduces P availability to crops (Singh et al., 1983).

Rock phosphates (phosphorites) are the only allowed mineral $\mathrm{P}$ source in organic farming (Commission Regulation [EC] n. 889/08 [EC, 2008]) but they are characterized by a low solubility (Singh et al., 1983) and a slow release of $\mathrm{P}$ over time. Thus, according to Rajan et al. (1996), their use should be planned to build fertility in the long-term more than to satisfy crop P needs in a short term perspective. Many studies have reported effective improved solubility of phosphorite-P, due to application of organic matter to the soil through green manures or composts (Alamgir and Marschner, 2016; Rick et al., 2011). Moreover, different authors highlighted the chance to obtain composts with high soluble $\mathrm{P}$ content by a phosphorite enrichment of the organic raw materials at the beginning of the composting process (Biswas et al., 2008; Nishanth and Biswas, 2008).

There is a lack of information about the possibility to properly combine compost or phosphorite application with green manures to improve $\mathrm{P}$ fertility in stockless systems in the Mediterranean area. Therefore, the hypothesis tested in this research was that different fertilization strategies could match with hairy vetch ( $\mathrm{Vi}$ cia villosa Roth.var. latigo) green manure in order to ensure a positive $\mathrm{P}$ balance, crop yield and $\mathrm{N}$ fertility. To accomplish this objective, a two-year field experiment was carried out in Central Italy under organic farming management. Since nutrient concentration of a plant give an integrated estimation of both total element uptakes and use, the investigation on biomass production, $\mathrm{N}$ and $\mathrm{P}$ content and balances were used to provide an in-depth insight into the effect of the analyzed approaches on $\mathrm{N}$ and $\mathrm{P}$ dynamics.

\section{Materials and Methods}

\subsection{Site, climate and soil}

A two-year field experiment was carried out in 2011 and 2012 at the Mediterranean Arable Systems COmparison Trial long-term experiment (MASCOT-LTE) located at the Centre for Agri-environmental Research "Enrico Avanzi" (CiRAA) of University of Pisa, Central Italy $\left(43^{\circ} 40^{\prime} \mathrm{N}, 10^{\circ} 19^{\prime} \mathrm{E}\right)$. Climatic conditions are typical of Mediterranean areas, with rainfall mostly concentrated in autumn (October to December) and spring (March to April). The soil is a loamy soil (Tipic Xeropsamment), containing $16.2 \mathrm{~g} \mathrm{~kg}^{-1}$ of organic matter, $12 \mathrm{mg} \mathrm{kg}^{-1}$ of Olsen available phosphorus (P), and having a $\mathrm{pH}$ value of 8.47 . Clay and silt contents are 23.0 and $33.3 \%$, respectively. Soil water content is 26.5 and $11.5 \%$ (as a percentage of soil-dry weight) at field capacity $(-0.03 \mathrm{MPa})$ and permanent wilting point (-1.5 MPa), respectively.

In the MASCOT LTE two cropping systems, one conventional and one organic, are being compared since 2001 based on the same 5-year stockless arablecrop rotation: grain maize (Zea mais L.) - durum wheat (Triticum durum Desf.) - sunflower (Helianthus annuus L.) - pigeon bean (Vicia faba L. var. minor) common wheat (Triticum aestivum L.). In the organic system, hairy vetch, grown in between wheat harvest and spring crop sowing (i.e. maize and sunflower), is 
incorporated into the soil as green manure (Mazzoncini et al., 2010).

Crop rotation is performed both in space and time, therefore each crop is present each year but on different fields. Each system is replicated three times for a total of 30 plots (15 organic and 15 conventional), with 0.35 ha real-field size per plot. Additionally, two series of five fields (the so called "playgrounds") have been included in-between the conventional and organic systems. The playgrounds, managed organically with the same crop rotation, serve the purpose to compare (in plot trials) different options for organic management of the five crops, still taking memory of the agronomic history of the system.

At sowing time, each crop in the organic system, apart pigeon bean, is fertilized with $1 \mathrm{Mg} \mathrm{ha}^{-1}$ of off-farm organic fertilizer (Nutex ${ }^{\circledR}$ Letame 3.3.3 - SIPCAM Italia) compliant with EU organic regulations and corresponding to $30 \mathrm{~kg} \mathrm{ha}^{-1}$ of $\mathrm{N}, 30 \mathrm{~kg} \mathrm{ha}^{-1}$ of $\mathrm{P}_{2} \mathrm{O}_{5}$ and $30 \mathrm{~kg} \mathrm{ha}^{-1}$ of $\mathrm{K}_{2} \mathrm{O}$. Additional $27 \mathrm{~kg} \mathrm{ha}^{-1}$ of $\mathrm{N}$ are provided with blood meal (Orgazot ${ }^{\circledR}$ 14-0-0 - AGM Srl) during both the durum and common wheat cropping cycles. For each crop, residues are incorporated into the soil with main tillage operations (namely, mouldboard ploughing $0.3 \mathrm{~m}$ depth for wheat and pigeon bean, chiselling $0.3 \mathrm{~m}$ depth for maize and sunflower). No irrigation is performed during the rotation.

\subsection{P rotation budget}

In order to determine the optimal $\mathrm{P}$ fertilization rate for organic fields, based on the experimental results of the first five years of the MASCOT LTE, P budget (surplus or deficit) of the whole crop sequence was preliminarily estimated according to the surface balance method (Oenema et al., 2003; Watson et al., 2002) as follows:

$$
\mathrm{P} \text { budget }\left(\mathrm{kg} \mathrm{ha}^{-1} \mathrm{yr}^{-1}\right)=\mathrm{P}_{\text {input }}-\mathrm{P}_{\text {output }}
$$

Where:

$\mathrm{P}_{\text {input }}: \mathrm{P}$ from organic fertilizers applied over the first five years of the experiment $\left(30 \mathrm{~kg} \mathrm{P}_{2} \mathrm{O}_{5} \mathrm{ha}^{-1} \mathrm{yr}^{-1}=13\right.$ $\mathrm{kg} \mathrm{ha}^{-1} \mathrm{yr}^{-1}$ of $\mathrm{P}$ for maize, sunflower, durum and common wheat);

$\mathrm{P}_{\text {output }}: \mathrm{P}$ uptake by maize, sunflower, pigeon bean, durum and common wheat yields measured in the first five years of the experiment.

The $\mathrm{P}$ uptake of crop residues was not included in the $\mathrm{P}_{\text {output }}$ since the residues were recycled into the soil system at the end of each crop cycle. The calculated $\mathrm{P}$ budget resulted in a $14 \mathrm{~kg} \mathrm{P}_{2} \mathrm{O}_{5} \mathrm{ha}^{-1} \mathrm{yr}^{-1}$ deficit (Mazzoncini, personal communication). On this basis, a dose of $24 \mathrm{~kg} \mathrm{ha}^{-1}$ of elemental $\mathrm{P}$ was estimated to be added to the system with the aim of shifting this balance on positive values.

\subsection{Experiment setup, treatments and measurements}

The experiment was carried out on two organic playground fields of the MASCOT long-term experiment (i.e. the two adjacent fields hosting the hairy vetchmaize sequence in the respective years) as a Completely Randomized Block design (CRB) in a splitplot with two factors and three replications. The main factor was the green manure (GM): absence (GM-) and presence $(\mathrm{GM}+)$ of hairy vetch cover crop before maize sowing. The second factor was the fertilization strategy ( $F$ ) of maize, and the following 5 treatments were compared: (i) negative control with no fertilizers (C), (ii) positive control with phosphorite $\left(\mathrm{C}^{+} \mathrm{a}\right)$, (iii) positive control with phosphorite plus not $\mathrm{P}$-enriched compost ( $\mathrm{C}^{+} \mathrm{b}$ ), (iv) not P-enriched compost (NEP), (v) P-enriched compost (EP) with rock phosphate added to organic raw materials at the beginning of the composting process. These materials were applied at the rate of $24 \mathrm{~kg} \mathrm{P} \mathrm{ha}^{-1}$, except the $\mathrm{C}^{+} \mathrm{b}$ treatment whose rate was calculated in order to supply with the compost the same amount of organic matter of the EP treatment, while 
the residual $\mathrm{P}$ rate was distributed as phosphorite (corresponding to 5.3 and $18.7 \mathrm{~kg} \mathrm{Pha}^{-1}$ by NEP and phosphorite, respectively). Treatment combinations were randomly assigned in the experimental area, obtaining 30 elementary plots of $8 \times 9 \mathrm{~m}^{2}$ each. Fertilizers and organic amendments (i.e compost) were added to the soil in one application at hairy vetch termination before maize sowing. Additional information about the composting process and the $\mathrm{P}$ content evaluation are reported in Mihreteab et al. (2016).

The main characteristics and compositions of the two composts (P-enriched and not P-enriched compost) are reported in Table 1.

Table 1. Chemical characteristics of the P-not enriched compost (NEP) and the P-enriched compost (EP) in 2011 and 2012.

\begin{tabular}{|c|c|c|c|c|}
\hline & \multicolumn{2}{|c|}{2011} & \multicolumn{2}{|c|}{2012} \\
\hline & NEP & EP & NEP & EP \\
\hline pH & 7.5 & 7.7 & 7.7 & 7.5 \\
\hline $\mathrm{EC}\left(\mathrm{dS} \mathrm{m} \mathrm{m}^{-1}\right)$ & 3.5 & 3.5 & 1.8 & 2.3 \\
\hline Organic C $\left({\left.\mathrm{g} 100 \mathrm{~g}^{-1}\right)^{1}}^{1}\right.$ & 35.9 & 32.3 & 37.6 & 36.0 \\
\hline Total N $\left({\left.\mathrm{g} 100 \mathrm{~g}^{-1}\right)^{2}}^{2}\right.$ & 2.5 & 2.6 & 2.2 & 2.1 \\
\hline $\mathrm{C}: \mathrm{N}$ & 14.4 & 12.7 & 17.1 & 16.9 \\
\hline Total $P\left(g 100 g^{-1}\right)^{3}$ & 0.4 & 1.8 & 0.4 & 1.5 \\
\hline Organic $P\left({\mathrm{~g} 100 \mathrm{~g}^{-1}}^{-1}\right)$ & 0.09 & 0.18 & 0.22 & 0.36 \\
\hline Soluble $\mathbf{P}\left(\mathrm{mg} \mathrm{kg}^{-1}\right)$ & 27 & 18 & 23 & 25 \\
\hline
\end{tabular}

The materials (feedstock) used to prepare the two types of compost were the same in each experimental year: grass clippings, palm, olive and ornamental pruning. In the EP compost, at the beginning of the composting process, finely ground rock phosphate ("fosforite" SACOM) was added at $100 \mathrm{~kg}$ per each $\mathrm{Mg}$ of fresh matter of the starting mixture. Both composts were prepared and monitored at the experimental compost facilities of the Mediterranean Agronomic Institute of Bari (CIHEAM - MAIB) in Southern Italy $\left(41^{\circ} 08^{\prime} \mathrm{N}\right.$; $\left.16^{\circ} 51^{\prime} \mathrm{E}\right)$.

Hairy vetch sowing in GM+ plots occurred on September $15^{\text {th }}$ and October $31^{\text {st }}$ in 2010 and 2011, respectively, at a seeding rate of $100 \mathrm{~kg} \mathrm{ha}^{-1}$. The cover crop was terminated by disc harrowing on April $8^{\text {th }}$ and April 24 $4^{\text {th }}$ in 2011 and 2012, respectively, when plants were producing the first pods at the end of flowering. The seedbed was prepared by rotary harrow, and grain maize (hybrid PR36Y03, FAO class 300) was sown on April $12^{\text {th }}$ and May $15^{\text {th }}$ in 2011 and 2012 , respectively, to obtain a plant density of 8 plants $\mathrm{m}^{-2}$ In 2011, grain maize was harvested on September $14^{\text {th }}$, with a cropping cycle of 155 days. In 2012, the harvest occurred on September $25^{\text {th }}$, with a cropping cycle of 133 days.

At hairy vetch termination, aboveground biomass of hairy vetch was measured by clipping all plant material at ground level within a $1 \mathrm{~m}^{2}$ area and oven-drying at $60{ }^{\circ} \mathrm{C}$ until constant weight. Furthermore, total $\mathrm{N}$ content (Kjeldahl method) of each sample was determined, allowing the calculation of the amount of $\mathrm{N}$ supplied by hairy vetch $\left(\mathrm{N}_{\text {input }}\right)$ to the system ( $\mathrm{N}$ content $\mathrm{x}$ biomass dry weight).

The effects of GM and F were evaluated during the entire maize cycle, until harvest, in order to study whether the treatments did affect or not the dynamics of growth, development and mineral nutrition of the crop. With this aim, plant and soil samples were collected at six maize stages: Sowing (BBCH 00), Emergence (BBCH 09), Stem Elongation (BBCH 33), Silking (BBCH 65), Grain Ripening (BBCH 89) and Harvest (BBCH 99) (BBCH: cereal growth staging scales as reported by Stauss, 1994). In 2011 the stages corresponded to 0-18-51-74-102-155 days after sowing (DAS), while in 2012 to 0-27-42-64-98-133 DAS. At each stage, soil mineral $\mathrm{N}\left(\mathrm{NO}_{3}^{-}-\mathrm{N}+\mathrm{NH}_{4}^{+}-\mathrm{N}\right)$ and available $\mathrm{P}\left(\mathrm{P}_{\text {avail }}\right)$ were measured at $30 \mathrm{~cm}$ soil depth. 
Soil mineral N (SMN) was extracted by $2 \mathrm{M} \mathrm{KCl} \mathrm{(1:10}$ $\mathrm{w} / \mathrm{v}$ ) and measured by continual flow colorimetry according to Krom (1980) and Henriksen and SelmerOlsen (1970) for $\mathrm{NH}_{4}^{+}-\mathrm{N}$ and $\mathrm{NO}_{3}^{-}-\mathrm{N}$, respectively. $\mathrm{P}_{\text {avail }}$ was extracted and measured according to the Olsen method.

At each stage, except the sowing one, aboveground maize crop biomass was collected within a randomly-selected 1.0 x $1.0 \mathrm{~m}$ area in each plot. At harvest stage, each maize plant was partitioned in cobs, grain and stovers. All plant materials were oven dried at 60 ${ }^{\circ} \mathrm{C}$ for $48 \mathrm{hr}$ until constant weight. The total $\mathrm{N}$ content (Kjeldahl method) of each sample at each stage, except for the emergence one, was determined, allowing the calculation of $\mathrm{N}$ uptake $(\mathrm{N}$ content $\mathrm{x}$ biomass dry weight) of each plant component, namely: total aboveground biomass (total biomass $\mathrm{N}$ ), cobs (cob $\mathrm{N})$, grain (grain $\mathrm{N}$ ) and the $\mathrm{N}$ of the stovers (stover $\mathrm{N}$ ). The total P content of each sample at each stage, except for the emergence one, was determined by inductively coupled plasma emission spectrophotometer (ICP-AES Iris; Thermo Optek, Milan, Italy), allowing the calculation of $\mathrm{P}$ uptake ( $\mathrm{P}$ content $\mathrm{x}$ biomass dry weight) of each plant component, namely: total aboveground biomass (total biomass $\mathrm{P}$ ), cobs (cob P), grain (grain P) and stovers (stover P).

All the plant and soil laboratory tests were carried out in three replicates in order to control intra-laboratory variability.

\section{4. $N$ and $P$ efficiency indices and balances}

At harvest stage the following $\mathrm{N}$ and $\mathrm{P}$ efficiency indices were calculated (Montemurro et al., 2006; Veneklaas et al., 2012):

1. NUsE (Nitrogen Use Efficiency): grain dry biomass / $\mathrm{N}$ applied by compost and green manure ( $\mathrm{kg}$ $\mathrm{kg}^{-1}$;
2. NRE (Nitrogen Recovery Efficiency): (total biomass $\mathrm{N}_{\text {fert }}$ - total biomass $\mathrm{N}_{\text {cont }}$ ) / $\mathrm{N}$ applied by compost and green manure $\left(\mathrm{kg} \mathrm{kg}^{-1}\right)$;

3. PUsE (Phosphorus Use Efficiency): grain dry biomass / P applied by compost and phosphorite $\left(\mathrm{kg} \mathrm{kg}^{-1}\right)$;

4. PRE (Phosphorus Recovery Efficiency): (total biomass Pfert - total biomass $\mathrm{P}_{\text {cont }}$ ) / P applied by compost and phosphorite $\left(\mathrm{kg} \mathrm{kg}^{-1}\right)$

Where:

total biomass $\mathrm{N}_{\text {fert }}$, total biomass $\mathrm{P}_{\text {fert }}$ are, respectively: the $\mathrm{N}$ and $\mathrm{P}$ uptake of total biomass in fertilized treatment $\left(\mathrm{C}^{+} \mathrm{a} ; \mathrm{C}^{+} \mathrm{b}\right.$; NEP; EP);

total biomass $\mathrm{N}_{\text {cont }}$, total biomass $\mathrm{P}_{\text {cont }}$ are, respectively: the $\mathrm{N}$ and $\mathrm{P}$ uptake of total biomass in the unfertilized control ( $\left.\mathrm{C}^{-}\right)$.

Soil-plant simplified $\mathrm{N}$ and $\mathrm{P}$ balances of the whole experiment were calculated (Oenema et al., 2003; Watson et al., 2002). The $\mathrm{N}$ balance was determined by the difference between the $\mathrm{N}$ supplied by vetch and compost and the crop $\mathrm{N}$ uptake at harvest, whereas the $\mathrm{P}$ balance was determined by the difference between the P supply by phosphorite and/or compost and the crop P uptake at harvest. The P and N uptake of crop stovers were considered among outputs despite their recycling into soil after crop harvest, in order to allow the evaluation of treatments capability to satisfy the whole crop requirements and give short period information on fertility strategies effectiveness.

\subsection{Statistical analysis}

Results on biomass, N, P parameters and efficiency indices were analyzed using univariate analysis of variance (ANOVA) considering year $(\mathrm{Y})$ as random factor, GM and $\mathrm{F}$ as fixed factors. Before analysis, the Levene test was performed to test the homogeneity of error variances, and appropriated data transformation was applied when necessary. Mean comparison was 
carried out according to the Tukey Test, at $\mathrm{P} \leq 0.05$ probability level. The elaboration was performed using the SPSS 22.0 package. carried out according to the Tukey Test, at $\mathrm{P} \leq 0.05$ probability level. The elaboration was performed using the SPSS 22.0 package.

\section{Results}

\subsection{Weather conditions and hairy vetch biomass pro- duction}

Climatic variation was high over the two years of the experiment (Figure 1).

Air temperature was near the long-term (30-yr) mean in both years, but differences were recorded for total rainfall. In particular, average rainfall in October December 2010 (549 mm) was $200 \mathrm{~mm}$ above the long-term mean and a peak precipitation occurred in April 2012 (160 mm vs $70 \mathrm{~mm}$ of long-term mean). Differently, unusual dry periods were recorded in April - May 2011 (29 mm vs $126 \mathrm{~mm}$ of long term mean), October 2011 - March 2012 (130 mm vs 538 $\mathrm{mm}$ of long term mean) and June - July 2012 ( $20 \mathrm{~mm}$ vs $54 \mathrm{~mm}$ of long term mean).

Hairy vetch biomass at termination date was significantly different between the two years (1.2 and 5.3 $\mathrm{Mg} \mathrm{ha}^{-1}$ of dry biomass in 2011 and 2012, respectively $\mathrm{P} \leq 0.001$ ), with a total $\mathrm{N}$ concentration of 2.4 and 3.7 g N $100 \mathrm{~g} \mathrm{~g}^{-1}$ of dry matter, corresponding to a significantly different $(\mathrm{P} \leq 0.001) \mathrm{N}$ supply to the system of 28.8 and $196.1 \mathrm{~kg} \mathrm{ha}^{-1}$ in 2011 and 2012, respectively.

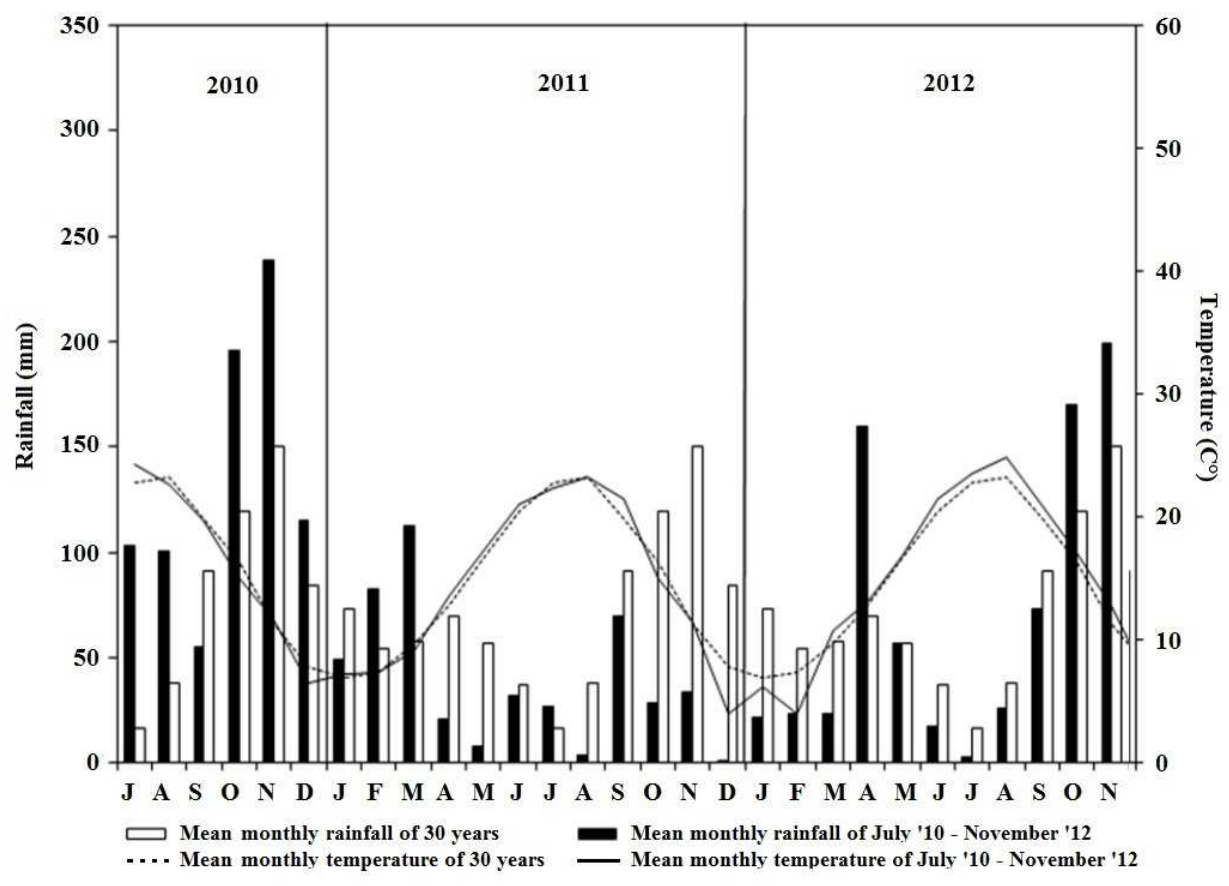

Figure 1. Mean monthly temperature and rainfall at the MASCOT Experimental site in San Piero a Grado - Pisa (July 2010 - November 2012) compared with the mean long-term. 


\subsection{Maize biomass}

The outputs of ANOVA considering the effect of the 3 factors (GM, F and Y) and their interactions on the dry matter produced by maize at harvest time in the two years are reported in Table 2.

The GM+ showed a significantly higher crop total aboveground dry biomass at silking $(+14 \%)$ and harvest stages $(+8 \%)$ than GM-. Although not significant, a similar trend was also recorded at the other cropping cycle stages. No significant difference was found among the different fertilization strategies. However, the use of EP fertilizer showed a grain yield of $2.5 \mathrm{Mg} \mathrm{ha}^{-1}$ in comparison with $1.8 \mathrm{Mg} \mathrm{ha}^{-1}$ averaged over the other $\mathrm{F}$ treatments $(\mathrm{P}=0.09)$. The effect of $\mathrm{Y}$ on total aboveground biomass of maize was significant only at grain ripening and harvest stages, when $87 \%$ and $41 \%$ higher values for 2011 than 2012 were observed, respectively.

Table 2. Results of the ANOVA for total maize dry biomass during the cropping cycle (total aboveground biomass) and biomass components (stover, cobs and grain) at Harvest stage in the two experimental years, as affected by green manure, fertilization, year and their mutual interactions.

\begin{tabular}{|c|c|c|c|c|c|c|c|}
\hline & \multicolumn{4}{|c|}{$\begin{array}{c}\text { Crop total aboveground } \\
\text { dry biomass } \\
\left(\mathrm{Mg} \mathrm{ha}^{-1}\right)\end{array}$} & \multicolumn{3}{|c|}{$\begin{array}{c}\text { Dry biomass components } \\
\text { at } \mathbf{H} \\
\left(\mathrm{Mg} \mathrm{ha}^{-1}\right)\end{array}$} \\
\hline & $\mathbf{E}^{\mathrm{a}} \mathbf{S E}$ & $\mathbf{S}$ & GR & H & Stover & Cobs & Grain \\
\hline \multicolumn{8}{|c|}{ Green Manure (GM) } \\
\hline GM- & 0.131 .1 & $4.4 \mathrm{~b}$ & 6.3 & $6.3 \mathrm{~b}$ & 3.5 & 0.59 & 2.1 \\
\hline \multirow[t]{2}{*}{ GM+ } & 0.222 .2 & $5.0 \mathrm{a}$ & 7.1 & $6.8 \mathrm{a}$ & 4.5 & 0.48 & 1.8 \\
\hline & Sig. n.s. n.s. & $*$ & n.s. & $*$ & n.s. & n.s. & n.s. \\
\hline \multicolumn{8}{|c|}{ Fertilizer $(\mathbf{F})^{\mathbf{a}}$} \\
\hline $\mathrm{C}^{-}$ & 0.171 .7 & 4.7 & 6.2 & 6.3 & 4.0 & 0.48 & 1.8 \\
\hline $\mathbf{C}^{+} \mathbf{a}$ & 0.181 .6 & 4.6 & 6.7 & 6.4 & 4.0 & 0.53 & 1.8 \\
\hline $\mathbf{C}^{+} \mathbf{b}$ & 0.191 .6 & 4.9 & 7.7 & 5.7 & 3.5 & 0.47 & 1.7 \\
\hline NEP & 0.171 .8 & 4.7 & 7.2 & 6.8 & 4.2 & 0.53 & 2.0 \\
\hline \multirow[t]{2}{*}{ EP } & 0.181 .6 & 4.4 & 5.8 & 7.5 & 4.3 & 0.67 & 2.5 \\
\hline & Sig. n.s. n.s. & n.s. & n.s. & n.s. & n.s. & n.s. & n.s. \\
\hline \multicolumn{8}{|l|}{ Year (Y) } \\
\hline 2011 & 0.111 .2 & 4.3 & $8.8 \mathrm{a}$ & $7.6 \mathrm{a}$ & 3.9 & 0.71 & 3.0 \\
\hline \multirow[t]{2}{*}{2012} & 0.242 .2 & 5.1 & $4.7 \mathrm{~b}$ & $5.4 \mathrm{~b}$ & 4.1 & 0.36 & 1.0 \\
\hline & Sig. n.s. n.s. & n.s. & $*$ & $*$ & n.s. & n.s. & n.s. \\
\hline Total mean & 0.181 .7 & 4.7 & 6.7 & 6.5 & 4.0 & 0.54 & 2.0 \\
\hline GM $x \mathbf{F}$ & n.s. n.s. & n.s. & n.s. & n.s. & n.s. & n.s. & n.s. \\
\hline GM $x$ Y & $* * * * *$ & n.s. & n.s. & n.s. & n.s. & n.s. & $*$ \\
\hline$F \times Y$ & n.s. n.s. & n.s. & n.s. & n.s. & n.s. & n.s. & n.s. \\
\hline GM $x$ F $x$ Y & n.s. n.s. & n.s. & n.s. & n.s. & n.s. & n.s. & n.s. \\
\hline
\end{tabular}


GM x Y interaction was found significant on total aboveground dry biomass at emergence and stem elongation stages and on grain yield at harvest. At completion of emergence, the highest total maize biomass was recorded for $\mathrm{GM}+$ in $2012\left(0.3 \mathrm{Mg} \mathrm{ha}^{-1}\right)$ and the lowest values in $2011\left(0.1 \mathrm{Mg} \mathrm{ha}^{-1}\right.$ averaged over GM+ and no GM- treatments) (data not showed). At stem elongation, the highest biomass value was recorded for $\mathrm{GM}+$ in $2012\left(2.8 \mathrm{Mg} \mathrm{ha}^{-1}\right)$ and the lowest value for GM-in $2011\left(0.9 \mathrm{Mg} \mathrm{ha}^{-1}\right)$ (data not showed). Grain yield showed the significantly highest value in 2011 (no significant difference between the GM treatments) whereas the lowest value was recorded in presence of vetch incorporated into the soil in 2012 (500\% lower than the 2011 mean value), as reported in Figure 2a. a

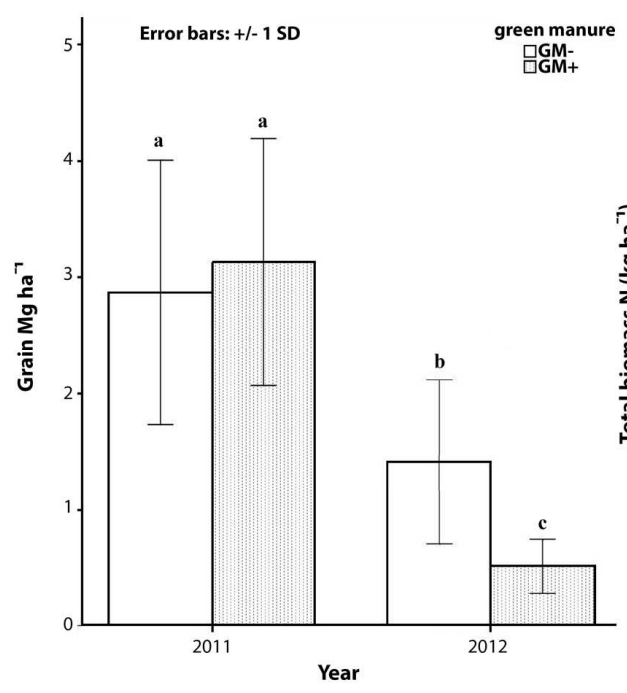

b

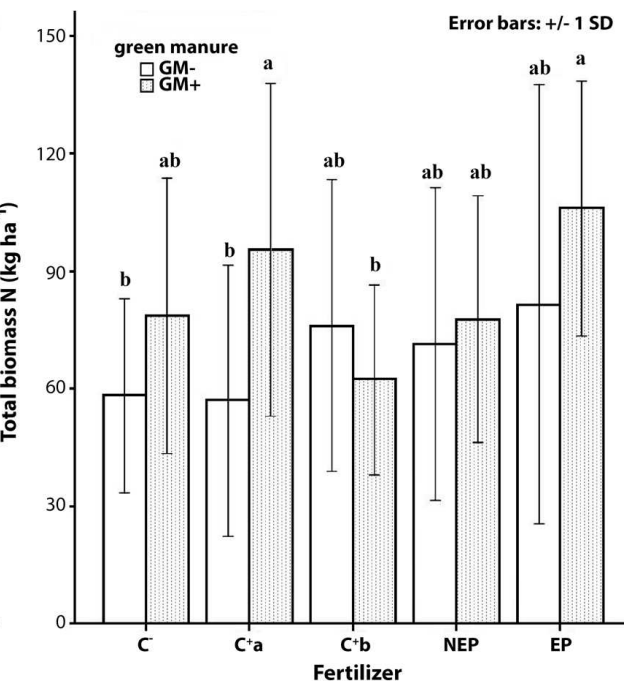

Figure 2. (a) Interaction effect of green manure (with and without) and experimental year (2011 and 2012) on grain yield of maize $\left(\mathrm{Mg} \mathrm{ha}^{-1}\right)$. (b) Interaction effect of green manure (with and without) and fertilization strategy on total aboveground biomass $\mathrm{N}$ uptake of maize at Harvest (averaged over the two experimental years).

\subsection{Soil mineral $N$ content and crop $N$ status}

Despite no significant difference was found for each experimental factor, higher SMN values in GM+ were recorded at all the sampling stages (Table 3).

Significant GM x Y interactions were found at sowing, emergence and harvest stages.
In particular, in 2012 at sowing stage the GM+ treatments showed the significantly highest SMN in 2012 $\left(51.6 \mathrm{mg} \mathrm{N} \mathrm{kg}^{-1}\right)$ and the GM- ones the significantly lowest $\left(20.3 \mathrm{mg} \mathrm{N} \mathrm{kg}^{-1}\right)$, whereas SMN showed intermediate values in 2011, with significant differences between GM treatments (32.9 and $27.4 \mathrm{mg} \mathrm{N} \mathrm{kg}^{-1}$ for $\mathrm{GM}+$ and GM-, respectively). 
In contrast, at emergence stage, the significant highest value was recorded for $\mathrm{GM}+$ in $2011\left(69.4 \mathrm{mg} \mathrm{N} \mathrm{kg}^{-1}\right)$, followed by GM- plots in 2011 (59.0 $\left.\mathrm{mg} \mathrm{N} \mathrm{kg}^{-1}\right), \mathrm{GM}+$ in 2012 (43.3 $\mathrm{mg} \mathrm{N} \mathrm{kg}^{-1}$ ) and GM-in 2012 (23.9 mg N $\mathrm{kg}^{-1}$ ), which was the lowest SMN value. At harvest the highest SMN value was recorded in 2012 for GM+ (50.4 $\mathrm{mg} \mathrm{N} \mathrm{kg}^{-1}$ ), whereas no significant difference was highlighted among other treatments, being 32.1 $\mathrm{mg} \mathrm{N} \mathrm{kg}{ }^{-1}$ for $\mathrm{GM}+$ in 2011 and 23.9 and $32.2 \mathrm{mg} \mathrm{N}$ $\mathrm{Kg}^{-1}$ for GM-in 2012 and 2011 respectively.

Table 3. ANOVA results for soil mineral nitrogen (SMN) during the cropping cycle, as affected by green manure, fertilization, year and their mutual interactions.

\begin{tabular}{|c|c|c|c|c|c|c|c|}
\hline & & \multicolumn{6}{|c|}{$\begin{array}{l}\text { Soil Mineral N content } \\
\text { (mg N kg-1 dry soil) }\end{array}$} \\
\hline & & Sow $^{\mathrm{a}}$ & $\mathbf{E}$ & SE & $\mathbf{S}$ & GR & $\mathbf{H}$ \\
\hline \multicolumn{8}{|c|}{ Green manure (GM) } \\
\hline GM- & & 23.8 & 41.4 & 22.1 & 23.3 & 20.9 & 28.0 \\
\hline GM+ & & 42.2 & 56.4 & 31.4 & 26.3 & 27.2 & 41.3 \\
\hline & Sig. & n.s. & n.s. & n.s. & n.s. & n.s. & n.s. \\
\hline \multicolumn{8}{|c|}{ Fertilizer $(\mathbf{F})^{\mathrm{a}}$} \\
\hline $\mathrm{C}^{-}$ & & 32.2 & 49.4 & 25.9 & 23.6 & 24.3 & 30.9 \\
\hline $\mathbf{C}^{+} \mathbf{a}$ & & 35.2 & 45.3 & 25.3 & 25.2 & 22.5 & 36.4 \\
\hline $\mathbf{C}^{+} \mathbf{b}$ & & 32.4 & 47.6 & 30.8 & 26.1 & 22.6 & 35.9 \\
\hline NEP & & 33.3 & 51.3 & 26.7 & 23.4 & 24.9 & 38.1 \\
\hline $\mathbf{E P}$ & & 32.0 & 50.9 & 25.2 & 25.7 & 26.0 & 31.9 \\
\hline & Sig. & n.s. & n.s. & n.s. & n.s. & n.s. & n.s. \\
\hline \multicolumn{8}{|l|}{ Year (Y) } \\
\hline 2011 & & 30.1 & 64.2 & 29.2 & 24.1 & 25.5 & 28.0 \\
\hline \multirow[t]{2}{*}{2012} & & 35.9 & 33.6 & 24.3 & 25.6 & 22.5 & 41.2 \\
\hline & Sig. & n.s. & n.s. & n.s. & n.s. & n.s. & n.s. \\
\hline Total mean & & 33.0 & 48.9 & 26.8 & 24.8 & 24.0 & 34.6 \\
\hline $\mathbf{G M} \times \mathbf{F}$ & & n.s. & n.s. & n.s. & n.s. & n.s. & n.s. \\
\hline GM x Y & & $* * *$ & $*$ & n.s. & n.s. & n.s. & $*$ \\
\hline $\mathbf{F} \times \mathbf{Y}$ & & n.s. & n.s. & n.s. & n.s. & n.s. & n.s. \\
\hline$G M \times F \times Y$ & & n.s. & n.s. & n.s. & n.s. & n.s. & n.s. \\
\hline
\end{tabular}


GM factor affected significantly total aboveground biomass $\mathrm{N}$ uptake of maize at grain ripening stage ( $40 \%$ higher $\mathrm{N}$ uptake in GM+ than in GM-) (Table 4). At grain ripening and harvest stages, in 2011 the results were significantly higher than in 2012 by $120 \%$ and 79\%, respectively. Significant GM x Y interaction was recorded at stem elongation and silking stages, showing the highest $\mathrm{N}$ uptake with vetch in 2011 and the lowest without vetch in 2012 (data not reported). Significant GM x F strategy was recorded at harvest, showing the highest values of total $\mathrm{N}$ uptake in the EP and $\mathrm{C}^{+}$a treatment under $\mathrm{GM}+$, and the lowest in the $\mathrm{C}^{-}$ and $\mathrm{C}^{+}$a treatment under GM- and in $\mathrm{C}^{+} \mathrm{b}$ under $\mathrm{GM}+$, as reported in Figure $2 b$.

Table 4. ANOVA results for $\mathrm{N}$ and $\mathrm{P}$ uptakes in total aboveground biomass (during the cropping cycle) and single biomass components (at harvest) of maize, as affected by green manure, fertilization, year and their mutual interactions.

\begin{tabular}{|c|c|c|c|c|c|c|c|c|c|c|c|c|c|c|c|}
\hline & & \multicolumn{4}{|c|}{$\begin{array}{c}\mathrm{N} \text { uptake in total } \\
\text { aboveground biomass } \\
\left(\mathrm{kg} \mathrm{N} \mathrm{ha}^{-1}\right)\end{array}$} & \multicolumn{3}{|c|}{$\begin{array}{c}\mathrm{N} \text { uptake in biomass } \\
\text { components at } \mathrm{H} \\
\left(\mathrm{kg} \mathrm{N} \mathrm{ha}^{-1}\right)\end{array}$} & \multicolumn{4}{|c|}{$\begin{array}{c}\text { P uptake in total aboveground } \\
\text { biomass } \\
\left(\mathrm{kg} \mathrm{P} \mathrm{ha}^{-1}\right)\end{array}$} & \multicolumn{3}{|c|}{$\begin{array}{c}\text { P uptake in biomass } \\
\text { components at } \mathrm{H} \\
\left(\mathrm{kg} \mathrm{P} \mathrm{ha}^{-1}\right)\end{array}$} \\
\hline & & $\mathbf{S E}^{\mathbf{a}}$ & $\mathbf{S}$ & GR & $\mathbf{H}$ & Stover & Cobs & Grain & SE & $\mathbf{S}$ & GR & $\mathbf{H}$ & Stover & Cobs & Grain \\
\hline \multicolumn{16}{|c|}{ Green Manure } \\
\hline GM- & & 17.0 & 45.7 & $65.1 \mathrm{~b}$ & 70.1 & 33.0 & 3.7 & 33.4 & $8.3 \mathrm{~b}$ & 21.3 & 23.0 & 32.7 & 14.4 & 0.6 & 18.0 \\
\hline GM+ & & 45.4 & 72.3 & $91.0 \mathrm{a}$ & 85.0 & 49.0 & 3.4 & 32.6 & $12.2 \mathrm{a}$ & 18.6 & 28.4 & 31.8 & 14.2 & 0.5 & 17.2 \\
\hline \multicolumn{16}{|c|}{ Fertilizer $(\mathbf{F})^{\mathbf{a}}$} \\
\hline $\mathbf{C}^{-}$ & & 31.4 & 58.4 & 73.8 & $69.7 \mathrm{~b}$ & 36.3 & 3.8 & 29.5 & 11.1 & 19.4 & 22.4 & 27.8 & 13.7 & 0.5 & 13.7 \\
\hline $\mathbf{C}^{+} \mathbf{a}$ & & 28.7 & 60.0 & 74.0 & $77.6 \mathrm{ab}$ & 40.8 & 4.0 & 32.8 & 10.1 & 19.2 & 25.1 & 31.9 & 14.4 & 0.6 & 17.1 \\
\hline $\mathbf{C}^{+} \mathbf{b}$ & & 29.2 & 61.3 & 87.2 & $70.5 \mathrm{~b}$ & 37.0 & 3.7 & 29.8 & 10.0 & 20.5 & 28.4 & 26.5 & 12.0 & 0.6 & 14.1 \\
\hline NEP & & 37.8 & 62.0 & 86.1 & $75.2 \mathrm{ab}$ & 40.4 & 2.5 & 32.3 & 11.0 & 18.8 & 28.8 & 32.8 & 13.9 & 0.4 & 18.7 \\
\hline EP & & 29.0 & 53.7 & 68.9 & $94.6 \mathrm{a}$ & 50.4 & 3.6 & 40.6 & 9.2 & 21.7 & 23.8 & 42.3 & 17.5 & 0.5 & 24.4 \\
\hline Year $(Y)$ & Sig. & n.s. & n.s. & n.s. & $*$ & n.s. & n.s. & n.s. & n.s. & n.s. & n.s. & n.s. & n.s. & n.s. & n.s. \\
\hline 2011 & & 17.9 & 64.7 & $107.3 \mathrm{a}$ & $100.1 \mathrm{a}$ & 45.6 & $4.7 \mathrm{a}$ & 49.8 & 10.4 & 13.0 & 39.2 & $49.1 \mathrm{a}$ & 17.3 & 0.6 & $31.1 \mathrm{a}$ \\
\hline 2012 & & 44.6 & 53.3 & $48.7 \mathrm{~b}$ & $55.9 \mathrm{~b}$ & 36.4 & $2.3 \mathrm{~b}$ & 16.2 & 10.2 & 26.9 & 12.2 & $15.4 \mathrm{~b}$ & 11.4 & 0.4 & $4.1 \mathrm{~b}$ \\
\hline & Sig. & n.s. & n.s. & $*$ & $*$ & n.s. & $*$ & n.s. & n.s. & n.s. & n.s. & $*$ & n.s. & n.s. & $* * *$ \\
\hline Total mean & & 31.2 & 59.0 & 78.0 & 77.5 & 41.0 & 3.5 & 33.0 & 10.3 & 19.9 & 25.7 & 32.2 & 14.3 & 0.5 & 17.6 \\
\hline GM $\times$ F & & n.s. & n.s. & n.s. & $*$ & n.s. & n.s. & n.s. & n.s. & $*$ & n.s. & n.s. & n.s. & n.s. & n.s. \\
\hline GM $\times$ Y & & $* * *$ & $*$ & n.s. & n.s. & $*$ & n.s. & $*$ & n.s. & n.s. & n.s. & n.s. & n.s. & n.s. & n.s. \\
\hline $\mathbf{F} \times \mathbf{Y}$ & & n.s. & n.s. & n.s. & n.s. & n.s. & n.s. & n.s. & n.s. & n.s. & n.s. & n.s. & n.s. & n.s. & n.s. \\
\hline GM $\times F \times Y$ & & n.s. & n.s. & n.s. & n.s. & n.s. & n.s. & n.s. & n.s. & n.s. & n.s. & n.s. & n.s. & n.s. & n.s. \\
\hline
\end{tabular}

aSE=Stem Elongation; $\mathrm{S}=$ Silking; GR=Grain Ripening; $\mathrm{H}=$ Harvest

\subsection{Soil available P content and crop P status}

No significant difference for soil $\mathrm{P}_{\text {avail }}$ was recorded for the different factors and their mutual interactions, with a stable mean value of $10 \mathrm{mg} \mathrm{P}_{\text {avail }} \mathrm{kg}^{-1}$ during the whole maize cropping cycle and in both years (data not reported).
Significant difference was recorded on total biomass $\mathrm{P}$ uptake at stem elongation stage when the GM+ treatments showed a $47 \%$ higher value than the GMones (Table 4).

Furthermore, in 2012 the P uptake was lower by $69 \%$ than 2011 at harvest stage. A significant GM 
$\mathrm{x} F$ interaction was also found in total biomass $\mathrm{P}$ at silking stage. At this stage the $\mathrm{P}$ uptake showed lower values in $\mathrm{C}^{-}, \mathrm{C}^{+} \mathrm{a}, \mathrm{C}^{+} \mathrm{b}, \mathrm{NEP}$ under $\mathrm{GM}+$ and in the unfertilized control $\left(\mathrm{C}^{-}\right)$under $\mathrm{GM}$ - than in the EP treatment under $\mathrm{GM}+$ and the fertilized treatments under GM- (C $\mathrm{C}^{+} \mathrm{a}, \mathrm{C}^{+} \mathrm{b}$, NEP and EP) (data not showed).

\section{5. $N$ and $P$ efficiency indices and balances}

Vetch green manure showed no significant effect on $\mathrm{N}$ and $\mathrm{P}$ efficiency indices (Table 5). On the other hand, the $\mathrm{F}$ factor showed significant differences in both NUsE and PUsE indices.

Table 5. ANOVA results for $\mathrm{N}$ and $\mathrm{P}$ efficiency indices, as affected by green manure, fertilization, year and their mutual interactions.

\begin{tabular}{|c|c|c|c|c|c|}
\hline & & \multicolumn{2}{|c|}{ Nitrogen } & \multicolumn{2}{|c|}{ Phosphorus } \\
\hline & & NUsE $^{a}$ & NRE & PUsE & PRE \\
\hline \multicolumn{6}{|c|}{ Green Manure (GM) } \\
\hline GM- & & 50.5 & 0.43 & 90.1 & -0.01 \\
\hline GM+ & & 39.1 & 0.40 & 77.7 & +0.01 \\
\hline & Sig. & n.s. & n.s. & n.s. & n.s. \\
\hline \multicolumn{6}{|l|}{ Fertilizer $(\mathbf{F})$} \\
\hline $\mathbf{C}^{-}$ & & $56.5 \mathrm{ab}$ & 0.49 & - & - \\
\hline $\mathbf{C}^{+} \mathbf{a}$ & & $74.7 \mathrm{a}$ & 1.03 & $75.5 \mathrm{~b}$ & -0.06 \\
\hline $\mathbf{C}^{+} \mathbf{b}$ & & $40.0 \mathrm{~b}$ & 0.28 & $72.3 \mathrm{~b}$ & -0.29 \\
\hline NEP & & $12.6 \mathrm{~b}$ & 0.10 & $83.9 \mathrm{~b}$ & -0.02 \\
\hline EP & & $55.5 \mathrm{ab}$ & 0.51 & $104.1 \mathrm{a}$ & +0.37 \\
\hline & Sig. & $* *$ & n.s. & $*$ & n.s. \\
\hline \multicolumn{6}{|l|}{ Year (A) } \\
\hline 2011 & & 77.7 & 0.66 & 129.1 & +0.18 \\
\hline \multirow[t]{2}{*}{2012} & & 13.1 & 0.16 & 38.8 & -0.18 \\
\hline & Sig. & n.s. & n.s. & n.s. & n.s. \\
\hline Total mean & & 43.4 & 0.41 & 83.95 & 0.00 \\
\hline GM $\times \mathbf{F}$ & & n.s. & n.s. & n.s. & n.s. \\
\hline GM x Y & & $*$ & n.s. & n.s. & n.s. \\
\hline $\mathbf{F} \times \mathbf{Y}$ & & n.s. & n.s. & n.s. & n.s. \\
\hline GM $x \mathbf{F} \times \mathbf{Y}$ & & n.s. & n.s. & n.s. & n.s. \\
\hline
\end{tabular}

${ }^{a} \mathrm{NUsE}=$ Nitrogen Use Efficiency; NRE=Nitrogen Recovery Efficiency; PUsE=Phosphorus Use Efficiency; PRE=Phosphorus Recovery Efficiency. 
For NUsE, the $\mathrm{C}^{+}$a treatment showed a significantly higher value by $87 \%$ and $493 \%$ than $\mathrm{C}^{+} \mathrm{b}$ and NEP, respectively. For PUsE, the EP recorded the highest value among treatments. Similarly, EP showed also the highest value for the PRE, although no significant difference was recorded for this result. A significant GM x Y interaction was found in NUsE. 2011 showed the significantly highest values (mean 73.0; no significant difference between the GM treatments) whereas the lowest value was recorded for GM+ in 2012 (2.3), whereas GM- treatment in 2012 (31.0) did not show significant difference with the other treatments (data not showed).
Finally, the $\mathrm{N}$ balance showed a significant interaction between GM and F, as reported in Figure 3a. The $\mathrm{N}$ surplus/deficit was significantly higher in NEP of GM+ $\left(+183 \mathrm{~kg} \mathrm{~N} \mathrm{ha}^{-1}\right)$ than in $\mathrm{C}^{-}, \mathrm{C}^{+} \mathrm{a}, \mathrm{C}^{+} \mathrm{b}$ and $\mathrm{EP}$ for GM- $\left(-56,-55,-39\right.$ and $-45 \mathrm{~kg} \mathrm{~N} \mathrm{ha}^{-1}$, respectively) and $\mathrm{C}^{+} \mathrm{a}$ for $\mathrm{GM}+\left(15 \mathrm{~kg} \mathrm{~N} \mathrm{ha}^{-1}\right)$. As far as the $\mathrm{P}$ balance was concerned, significant difference was found among fertilization treatments (Figure 3b).

The unfertilized control ( $\left.\mathrm{C}^{-}\right)$showed the lowest value and the $\mathrm{C}^{+} \mathrm{b}$ the highest one $\left(-28\right.$ and $-2 \mathrm{~kg} \mathrm{P} \mathrm{ha}{ }^{-1}$, respectively). 


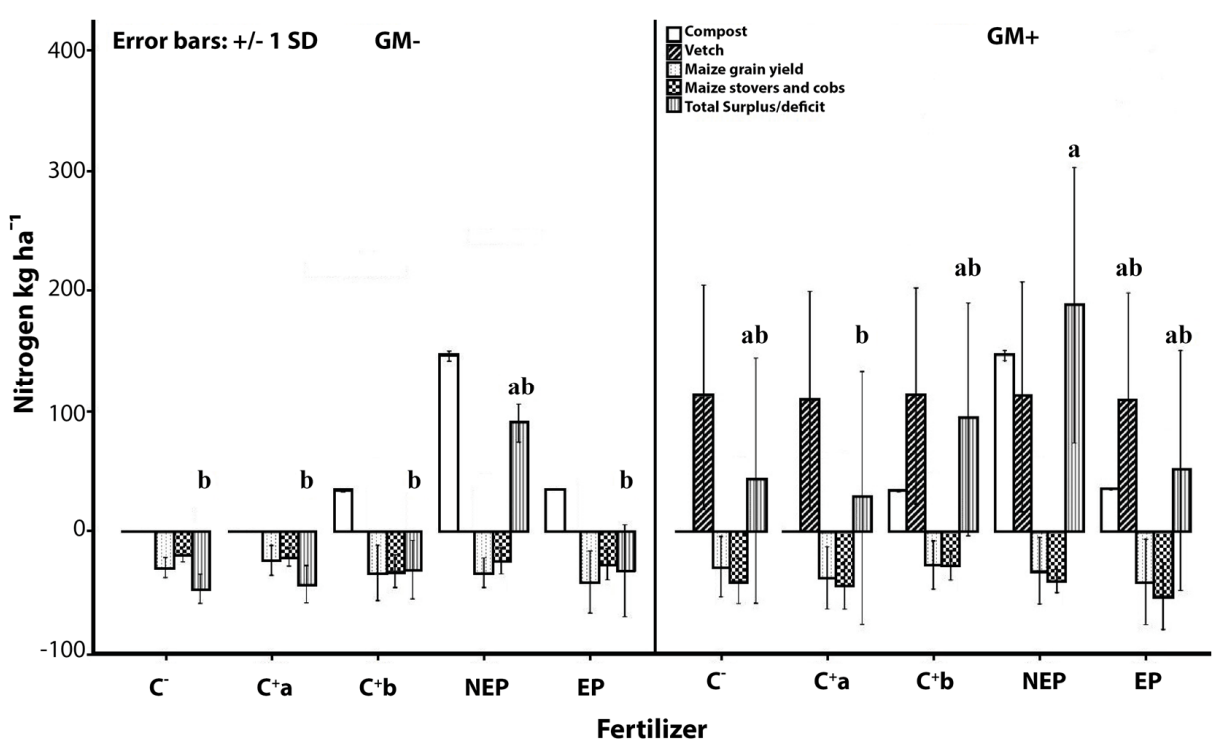

b

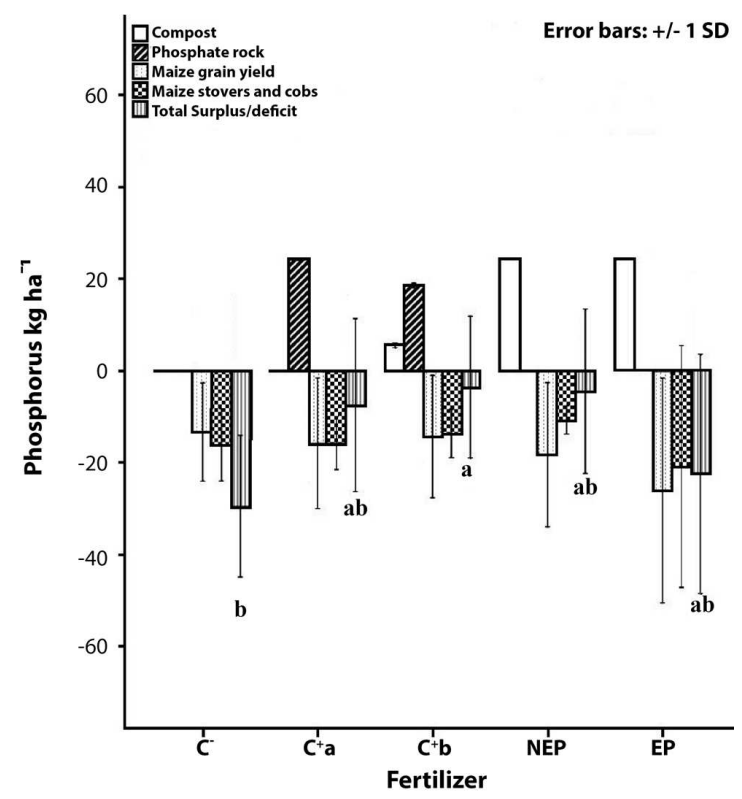

Figure 3. (a) Soil $\mathrm{N}$ surplus/deficit $\left(\mathrm{kg} \mathrm{N} \mathrm{ha}^{-1}\right)$ for the maize growing season of the whole experiment split by fertilizer treatments $\mathrm{x}$ green manure. (b) Soil P surplus/deficit $\left(\mathrm{kg} \mathrm{P} \mathrm{ha}^{-1}\right)$ for the maize growing season of the whole experiment split by fertilizer treatments. 


\section{Discussion}

The high rainfalls recorded consequently to hairy vetch sowing in the first year (September 2010; Figure 1) strongly reduced green manure germination and early development, causing its low biomass production and $\mathrm{N}$ fixation at termination date. On the contrary, in the second year hairy vetch produced higher biomass and $\mathrm{N}_{\text {input }}\left(193.5 \mathrm{~kg} \mathrm{~N}\right.$ ha $\left.^{-1}\right)$ to the system than in 2011, although the winter months were drier than the long-term average rainfall. This result is in accordance with Cook et al. (2010), who pointed out how the variability of biomass production in function of climatic conditions was one of the main constraints in estimation of $\mathrm{N}$ supplied by vetch to the following crop in rotation. In our experiment, these inter-annual differences affected the early maize development and biomass production in the two years, as pointed out by the significant interaction between GM and $\mathrm{Y}$ at stem elongation and silking stages (Table 2). Indeed, the maize biomass in GM+ was significantly higher in 2012 than in 2011. On the other hand, the grain yield of maize at harvest maturity showed a significant reduction in 2012 in comparison with 2011, in particular in GM+ treatments (Figure 2a). This result was probably due to the dry conditions occurred after vegetative growth in the June-August 2012, in correspondence of the grain formation and ripening stages (Figure 1). Indeed, maize is resistant to water deficit in the vegetative stages, whereas water stress occurring during grain formation and ripening stages can strongly reduce maize yield (Cakir, 2004). Furthermore, water stress effect can be magnified by the water uptake of the preceding crops, with consequently significant yield depletion in main crops following winter cover crops (Koerner and Power, 1987). Despite this, the hairy vetch green manure significantly increased maize $\mathrm{N}$ uptake, as showed by the higher total biomass $\mathrm{N}_{\text {in }} \mathrm{C}^{+}$a treat- ment (which did not receive compost as $\mathrm{N}$ source) under GM+ than GM- (Figure 2b).

Similar. but not significant result, was showed by $\mathrm{C}$ treatment under GM+ in comparison to GM-. Since the SMN resulted higher or equal in $\mathrm{GM}+$ plots than in the GM- ones during the whole cropping cycle (Table 3), the lower maize yield observed for GM+ in 2012 than in 2011 was not due to $\mathrm{N}$ limiting availability, as also confirmed by the higher total biomass $\mathrm{N}$ of GM+ than in GM- (Table 4). Furthermore, in our study we did not found a significant effect of vetch green manure on $\mathrm{P}$ soil availability and maize $\mathrm{P}$ uptake in all growing stages.apart the stem elongation stage (Table 4). This finding is not in accordance with other studies in which legume green manures were found to significantly increase soil $\mathrm{P}$ availability (Cavigelli and Thien, 2003). Further analysis should be carried out in order to evaluate the effect of tested vetch variety (i.e. cv. latigo) on $\mathrm{P}$ dynamics and availability in the soil.

As far as the fertilization strategy is concerned, the absence of strong differences among the tested treatments for $\mathrm{N}$ and $\mathrm{P}$ soil availability, confirms that compost and rock phosphates should not be used to satisfy the short-term $\mathrm{N}$ and P plant requirements, but to build up the long term soil fertility (Rajan et al., 1996; Diacono and Montemurro, 2010). Despite this, N uptake results showed a different pattern accordingly to fertilizer and green manure combinations, as reported in Figure $2 b$. The lack of difference between $P$ fertilizers (i.e. $\mathrm{C}^{+}$b, NEP, EP) and the unfertilized control ( $\mathrm{C}^{-}$) in GM- plots highlighted that the composts alone were not able to improve maize $\mathrm{N}$ nutrition in the short period. At the same time, none of the P-fertilized treatments showed significant differences between GM+ and GM- in terms of crop $\mathrm{N}$ uptake, highlighting the potential of the composts to sustain crop $\mathrm{N}$ requirements despite the green manure absence. The results of total biomass $\mathrm{P}$ at silking stage showed higher $\mathrm{P}$ up- 
take in maize fertilized with composts (i.e. $\mathrm{C}^{+} \mathrm{b}, \mathrm{NEP}$, EP) than the unfertilized control $\left(\mathrm{C}^{-}\right)$when vetch was not grown before. This result could be likely related to an effect of the organic matter present in the compost on soil P solubility in the central stage of maize cycle. Indeed, Habib et al. (1994) reported a positive effect on P soluble fraction with soil application of organic amendments.

The higher $\mathrm{N}$ use efficiency of the treatment with phosphorite only $\left(\mathrm{C}^{+} \mathrm{a}\right)$ than the $\mathrm{C}^{+} \mathrm{b}$ and NEP (Table 5 ) indicated that composts were not able to increase $\mathrm{N}$ use efficiency of maize averaged over GM treatments. Concerning the lower NUsE observed in the second year compared to the year before, the controversial dry weather conditions occurred in 2012 (which actually, on one hand, favored vetch growth and determined high vetch $\mathrm{N}_{\text {input }}$, and on the other hand limited maize growth and biomass production at harvest) were likely the main reasons behind. According to the $\mathrm{N}$ balance (Figure $3 \mathrm{a}$ ), the fertilization strategies with phosphorite applied directly to the soil or during the composting process $\left(\mathrm{C}_{\mathrm{a}}^{+} ; \mathrm{C}_{\mathrm{b}}^{+}\right.$and $\left.\mathrm{EP}\right)$ showed conditions of $\mathrm{N}$ deficit when not associated to vetch green manure. As a consequence, although crop stovers are recycled into the soil at the end of the cropping cycle, our results underlined $\mathrm{N}$ as possible limiting factor in these treatments when scarce $\mathrm{N}_{\text {input }}$ by hairy vetch occurs, determining a potential risk of yield depletion.

The calculation of $\mathrm{P}$ balance showed that $\mathrm{P}$ supplied by all the P-fertilizers was much lower than P removed from the system by stovers and grain of the maize crop (Figure 3b). Our results underlined that, in our conditions, soil amendment with P-fertilizers did not allow meeting maize $P$ requirements, thus additional efforts should be put in increasing the plant availability of soil P pool during cropping cycle (e.g. by including more leguminous species in crop rotations, by correcting soil $\mathrm{pH}$, by using products containing P-solubilizing active compounds or microbials). Nevertheless, this deficit can be considered very close to the amount of $\mathrm{P}$ accumulated in crop stovers and re-integrated into the soil after maize harvest (Figure 3b). Indeed, by considering only the grain $\mathrm{P}$ uptake as output, the $\mathrm{P}$ balance raise positive value for $\mathrm{C}^{+} \mathrm{a}\left(+7 \mathrm{~kg} \mathrm{P} \mathrm{ha}^{-1}\right), \mathrm{C}^{+} \mathrm{b}$ $\left(10 \mathrm{~kg} \mathrm{P} \mathrm{ha}^{-1}\right)$ and NEP $\left(+6 \mathrm{~kg} \mathrm{P} \mathrm{ha}{ }^{-1}\right)$ as far as $0 \mathrm{~kg}$ $\mathrm{P} \mathrm{ha}^{-1}$ for EP while maintaining a deficit condition in $\mathrm{C}^{-}\left(-14 \mathrm{~kg} \mathrm{P}^{-1}\right)$. Our result put in evidence that the chosen strategies were not contributing to a P mining condition of the studied cropping system. Moreover, among the P-fertilizers treatments, the EP compost showed the highest $\mathrm{P}$ use efficiency, being able to increase also the crop yield.

\section{Conclusions}

In conclusion, our study pointed out the possibility to combine different agronomic strategies, to obtain adequate yield, reduce of soil $\mathrm{P}$ mining condition and improve nutrient use efficiency, in respect with the need to manage soil $\mathrm{P}$ fertility despite the absence of products of animal origin in organic stockless farming systems. In particular, the leguminous green manure is confirmed to have a key role in managing the $\mathrm{N}$ soil fertility in the short run, even if no evidence on $\mathrm{P}$ availability was noted. On the other hand, the $\mathrm{P}$ enrichment during the composting process highlighted as a potential valuable solution to maintain $\mathrm{P}$ balance, ensuring a higher efficiency of $\mathrm{P}$ use by using a compost of plant origin. The combined use of leguminous green manure and enriched $\mathrm{P}$ compost can be then considered as a concrete option in order to manage the $\mathrm{N}$ and $\mathrm{P}$ fertility in the short and long runs and to sustain plant requirements.

The obtained results emphasize that, even in stockless systems, it is possible to predict strategies of $\mathrm{P}$ mining reintegration without the need to resort to products of animal origin. Further researches aiming at evaluate the effectiveness of these strategies on 
nutrient balance in the entire system should be highly encouraged, through the application of the selected materials and doses for the minimum duration of an entire crop rotation. This could help to evaluate the potential of the technique to increase $\mathrm{N}$ - P utilization at system level, and improve soil protection, organic matter preservation and long term soil fertility.

\section{Acknowledgements}

The authors wish to thank Alberto Alianello, Andrea Marcucci and Federica Bigongiali for their contribution to the process of field operations, soil and plant sampling and analysis, and to Adel Aly for compost analysis.

This paper is a result of the COMPARABIMUS (2010-2013) research project (Compost use in Mediterranean organically managed arable Stockless cropping systems) funded by the Research Office of the Italian Ministry of Agriculture.

\section{References}

Alamgir, M., Marschner, P. 2016. Changes in pools over three months in two soils amended with legume residues. J. Soil. Sci. Plant. Nut., 16, 76-87.

Biswas, D.R., Narayanasamy, G., Datta, S.C., Singh, G., Begum, M., Maiti, D., Mishra, A., Basak, B.B. 2009. Changes in nutrient status during preparation of enriched organomineral fertilizers using rice straw, low-grade rock phosphate, waste mica, and phosphate solubilizing microorganism. Commun. Soil Sci. Plant Anal., 40, 2285-2307.

Cakir, R. 2004. Effect of water stress at different development stages on vegetative and reproductive growth of corn. Field Crops Res. 89, 1-16.

Canali, S., Ciaccia, C., Tittarelli, F. 2012. Soil fertility management in organic potato: the role of green manure and amendment application. In:
H. Zhongqi, R. Larkin, W. Honeycutt (eds). Sustainable Potato Production: Global Case Studies. Springer publisher, pp 454-469.

Cavigelli, M.A., Thien, S.J. 2003. Phosphorus bioavailability following incorporation of green manure crops. Soil Sci. Soc. Am. J. 67, 1186-1194.

Cook, J.C., Gallagher, R.S., Kaye, J.P., Lynch, J., Bradley, B. 2010. Optimizing vetch nitrogen production and corn nitrogen accumulation under notill management. Agron. J. 102, 1491-1499.

De Ponti, T., Rijk, B., van Ittersum, M. 2012. The crop yield gap between organic and conventional agriculture. Agr. Syst. 108, 1-9.

Diacono, M., Montemurro, F., 2010. Long-term effect of organic amendments on soil fertility. A review. Agron. Sustainable Dev. 30, 401-422.

EC Regulation. 2007. 2007/834/CE of the Council, $28^{\text {th }}$ June 2007. Official Journal of European Communities.

EC Regulation. 2008. 2008/889/CE of the European Commission, 5th September 2008. Official Journal of European Communities.

Eghball, B., Ginting, D., Gilley, J.E. 2004. Residual effects of manure and compost applications on corn production and soil properties. Agron. J. 96, 442-447.

EIP-AGRI Focus Group on Organic Farming. 2014. Optimising arable yields. Recommendations and outputs. http://ec.europa.eu (acessed 20.06.16).

Habib, L., Hayfa, S., Ryan, J. 1994. Phosphorus solubility changes with time in organically amended soil in a Mediterranean environment. Communication in Soil Science and Plant Anlaysis. 25, 3281-3290.

Henriksen, A., Selmer-Olsen, A.R. 1970. Automatic methods for determining nitrate and nitrite in water and soil extracts. Analyst. 95, 514-518. 
Koerner, P.T., Power, J.F. 1987. Hairy vetch winter cover for continuous corn in Nebraska. In: J. F. Power (ed). The role of legumes in conservation tillage systems - Soil Conservation Society of America. The proceedings of a national conference University of Georgia, Athens.

Krom, M.D. 1980. Spectrophotometric determination of ammonia: a study of a modified Berthelot reaction using salicylate and dichloroiso cyanurate. Analyst. 105, 305-316.

Mahmood, F., Khan, I. Ashraf, U., Shahzad, T., Hussain, S., Shahid, M., Abid, M., Ullah, S. 2017. Effects of organic and inorganic manures on maize and their residual impact on soil physicochemical properties. J. Soil. Sci. Plant. Nut. 17, 22-23.

Mazzoncini, M., Canali, S., Giovannetti, M., Castagnoli, M., Tittarelli, F., Antichi, D., Nannelli, R., Cristani, C., Bàrberi, P. 2010. Comparison of organic and conventional stockless arable systems: a multidisciplinary approach to soil quality evaluation. Appl. Soil Ecol. 44, 124-132.

Migliorini, P., Moschini, V., Tittarelli, F., Ciaccia, C., Benedettelli, S., Vazzana, C., Canali, S. 2014. Agronomic performance, carbon storage and nitrogen utilisation of long-term organic and conventional stockless arable systems in Mediterranean area. Eur. J. Agron. 52, 138-145.

Mihreteab, H.T., Ceglie, F., Aly, A., Tittarelli, F. 2016. Rock phosphate enriched compost as a growth media component for organic tomato (Solanum lycopersicum L.) seedlings production. Biol. Agric. Hotic. 32, 7-20.

Montemurro, F., Maiorana, M., Ferri, D. Convertini, G. 2006. Nitrogen indicators, uptake and utilization efficiency in a maize and barley rotation cropped at different levels and sources of $\mathrm{N}$ fertilization. Field Crop Res. 99, 114-124.
Nelson, O.N., Janke, R.R. 2007. Phosphorus sources and management in organic production systems. Horttechnology. 17, 442-454.

Nishanth, D., Biswas, D.R., 2008. Kinetics of phosphorus and potassium release from rock phosphate and waste mica enriched compost and their effect on yield and nutrient uptake by wheat (Triticum aestivum). Bioresource Technol. 99, 3342-3353.

Oenema, O., Kros, H. de Vries, W. 2003. Approaches and uncertainties in nutrient budgets: implications for nutrient management and environmental policies. Eur. J. Agron. 20, 3-16.

Rahmann, G., Ardakani, M.R., Bàrberi, P., Böhm, H., Canali, S., Chander, M., David, M., Dengel, L., Erisman, J.W., Galvis-Martinez, A.C., Hamm, U., Kahl, J., Köpke, U., Kühne, S., Lee, S.B., Loes, A.K., Moos, J.H., Neuhoff, D., Nuutila, J.J., Oppermann, R., et al. 2016. Organic Agriculture 3.0 is innovation with research. Organic Agriculture. DOI 10.1007/s13165-016-0171-5.

Rajan, S.S.S., Watkinson, J.H., Sinclair, A.G. 1996. Phosphate rocks for dirt application to soils. Adv. Agron. 57, 77-159.

Reganold, J.P., Wachter, J.M. 2016. Organic agriculture in the twenty-first century. Nat. Plants, 2, 15221.

Rick, T.L., Jones, C.A., Engel, R.E. 2011. Green manure and phosphate rock effects on phosphorus availability in a northern Great Plains dryland organic cropping system. Organic Agriculture. 8, 81-90.

Schulte, R.P.O., Creamer, R.E., Donnellan, T., Farrelly, N., Fearly, R., O’Donoghue, C., O'huallachain, D. 2013. Functional land management: a framework for managing soil-based ecosystem services for the sustainable intensification of agriculture. Environ. Sci. Polic. 38, 45-58. 
Shah, G.M., Shah, G.A., Groot, J.C.J., Raza, M.A.S., Shahid, N., Lantinga E.A. 2016. Maize nitrogen recovery and dry matter production as affected by application of solid cattle manure subjected to various storage conditions. J. Soil. Sci. Plant. Nut. 16, 591-603.

Singh, C.P., Ruhal, D.S., Singh, M. 1983. Solubilisation of low grade rock phosphate by composting with a farm waste, pearl-millet Boobla. Agr. Wastes. 8, 17-25.

Stauss, R. 1994. Compendium of growth stage identification keys for mono- and dicotyledonous plants: extended BBCH scale. Ciba-Geigy AG.
Stinner, W., Moller, K., Leithold, G. 2008. Effects of biogas digestion of clover/grassleys, cover crops and crop residues on nitrogen cycle and crop yield in organic stockless farming systems. Eur. J. Agron. 29, 125-134.

Veneklaas, E.J., Lambers, H., Bragg, J., Finnegan, P.M., Lovelock, C.E., Plaxton, W.C., Price, C.A., Scheible, W.R., Shane, M.W., White, P.J., Raven, J.A. 2012. Opportunities for improving phosphorus-use efficiency in crop plants. New Phitol. 195, 306-320.

Watson, C.A., Atkinson, D., Gosling, P., Jackson, L., Rayns, F.W. 2002. Managing soil fertility in organic farming systems. Soil Use Manage. 18, 239-247. 